\title{
PARTISIPASI MASYARAKAT DALAM PROGRAM DESA TERNAK MANDIRI (DTM) DOMPET PEDULI UMAT DARUUT TAUHIID (DPU-DT) DI NESA NEGLASARI KECAMATAN MAJALAYA KABUPATEN BANDUNG
}

\author{
Oleh: \\ Fiki Hari Nugraha, Agus Wahyudi Riana, \& Maulana Irfan \\ Email: \\ fikihari@gmail.com
}

\begin{abstract}
ABSTRAK
Masalah sosial yang ada di Indonesia sangatlah banyak salah satunya yaitu fenomena kemiskinan, kemiskinan disini terbagi menjadi 2 dimensi atau di katagori yaitu kemiskinan di kota dan kemiskinan di desa. Contoh kemiskinan di desa salah satunya di Desa Neglasari Kecamatan Majalaya Kabupaten Bandung, Desa Neglasari merupakan daerah basis ekonomi pertanian dan perternakan di daerah majalaya yang sebagian besar wilayahnya merupakan kawasan pertanian dan lahan ternak. Namun, Desa Neglasari pun termasuk ke dalam penduduk miskin yang tinggi. Menurut data Desa Neglasari memiliki 3.062KK yang mayoritas dari kalangan keluarga pra sejahtera Undang-undang No.10 tahun 1992 menyebutkan bahwa keluarga pra sejahtera adalah keluarga yang belum dapat memenuhi kebutuhan dasarnya, belum mampu memenuhi kebutuhan makan minimal dua kali sehari, pakaian yang berbeda untuk di rumah, bekerja, sekolah, dan berpergian, memiliki rumah yang bagian lantainya bukan dari tanah, dan belum mampu untuk berobat di sarana kesehatan moderen. Hal ini sesuai dengan keadaan penduduk Desa Neglasari yang mayoritas menjadi buruh tani dan buruh ternak dengan penghasilan rata-rata Rp 35.000/hari, yang tentunya tidak mencukupi untuk kebutuhan seharihari serta biaya pendidikan tanggungan keluarga lainnya. Dalam mengahadapi masalah kemiskinan, salah satu pendekatan pemecahan masalah kemiskinan di pedesaan yang dapat dilakukan adalah pemberdayaan masyarakat (community empowerment). Pemberdayaan masyarakat menjadi salah satu pendekatan yang kini sering digunakan dalam meningkatkan kualitas kehidupan dan mengangkat harkat martabat keluarga miskin. Selain pemerintah pun organisasi-organisasi pelayanan sosial pun melakukan hal sama dalam konsep pemberdayaan masyarakat. Desa Neglasari merupakan salah satu sasasran DPU DT dalam melaksanakan program DTM wilayah Jawa Barat. Penentuan lokasi atau sasaran penerima program tersebut melihat tingkat keluarga pra sejahtera yang tinggi, potensi pertanian, perternakan, juga sumber daya peternak yang harus dikembangkan, serta berusaha memperluas jaringan wilayah penerima program DTM di sekitar kabupaten Majalaya.
\end{abstract}

Key Words : Kemiskinan, Pemberdayaan Masyarakat, Partisipasi Masyarakat, DPU-DT, Desa Ternak Mandiri.

\section{PENDAHULUAN}

Kemiskinan adalah keadaan dimana terjadi ketidakmampuan untuk memenuhi kebutuhan dasar seperti makanan, pakaian, tempat berlindung, pendidikan, dan kesehatan. Kemiskinan dapat disebabkan oleh kelangkaan 
alat pemenuhan kebutuhan dasar, ataupun sulit akses terhadap pendidikan dan pekerjaan. Kemsikinan merupakan masalah global. Sebagian orang memahami istilah ini secara subyektif dan komparatif, sementara yang lainnya melihat dari segi moral dan evaluatif,

Tabel 1.1 dan yang lainnya lagi memahami dari sudut ilmiah yang telah mapan. Berikut adalah data atau fakta mengenai kemiskinan di Jawa Barat yang memang memiliki jumlah yang cukup besar bila di bandingkan dengan provinsi lain.

Jumlah Penduduk Miskin Menurut Provinsi, September 2014

\begin{tabular}{|c|c|c|c|c|c|}
\hline & \multicolumn{2}{|c|}{ Jumlah Penduduk Miskin } & \multirow[b]{2}{*}{ Kota+Desa } & \multicolumn{2}{|c|}{ Persentase Penduduk Miskin (\%) } \\
\hline & Kota & Desa & & Kota & Desa \\
\hline Aceh & 158,04 & 679,38 & 837,42 & 11,36 & 19,19 \\
\hline Sumatera & 667,47 & 693,13 & 1360,6 & 9,81 & 9,89 \\
\hline Sumatera & 108,53 & 246,21 & 354,74 & 5,41 & 7,84 \\
\hline Riau & 159,53 & 338,75 & 498,28 & 6,53 & 8,93 \\
\hline Kepulauar & 91,27 & 32,9 & 124,17 & 5,61 & 10,54 \\
\hline Jambi & 109,07 & 172,68 & 281,75 & 10,67 & 7,39 \\
\hline Sumatera & 370,86 & 714,94 & 1085,8 & 12,96 & 13,99 \\
\hline Bangka Be & 20,27 & 46,96 & 67,23 & 3,04 & 6,84 \\
\hline Bengkulu & 99,59 & 216,91 & 316,5 & 17,19 & 17,04 \\
\hline Lampung & 224,21 & 919,73 & 1143,93 & 10,68 & 15,46 \\
\hline DKI Jakart & 412,79 & 0 & 412,79 & 4,09 & 0 \\
\hline Jawa Bara & 2554,06 & 1684,9 & 4238,96 & 8,32 & 10,88 \\
\hline
\end{tabular}

Sumber : Bada Pusat Statistik 2013-2014

Tabel 1 menunjukan di Jawa Barat memiliki jumlah kemiskinan yang cukup besar bila di bandingkan dengan Provinsi lain, khususnya kemiskinan di wilayah pedesaan menjadi salah satu permaslahan yang disebabkan minimnya akses lapangan pekerjaan dan rendahnya kepemilikan modal, sehingga hal tersebut menjadi sangat wajar terjadi di daerah pedesaan. Namun tingkat pendidikan yang rendah dan minimnya keterampilan menjadikan mereka tersisih dan hanya menjadi beban perkotaan.

Kondisi diatas jelas memprihatinkan, realita kemiskinan bukanlah permasalahan yang mudah diatasi mengingat kondisi yang harus di tanggulangi mencakup banyak segi. Kepemilikan yang tidak merata dan kemampuan masyarakat yang terbatas.

Desa Neglasari merupakan daerah basiss ekonomi pertanian dan perternakan di daerah Majalaya yang sebagian besar wilayahnya merupakan kawasan pertanian dan lahan ternak. Namun, Desa Neglasari pun termasuk ke dalam daerah yang memiliki penduduk miskin yang tinggi. Menurut data desa neglasari memiliki $3.062 \mathrm{KK}$ yang mayoritas dari kalangan keluarga pra sejahtera. Undang-undang No.10 tahun 1992 menyebutkan bahwa keluarga pra sejahtera adalah keluarga yang belum dapat memenuhi kebutuhan dasarnya, belum mampu memenuhi kebutuhan makan minimal dua kali sehari, pakaian yang berbeda untuk di rumah, bekerja, sekolah, dan berpergian, memiliki rumah yang bagian lantainya bukan dari tanah, dan belum mampu untuk berobat di sarana kesehatan moderen. Hal ini sesuai dengan keadaan penduduk Desa Neglasari yang mayoritas menjadi buruh tani dan buruh ternak dengan penghasilan rata-rata Rp 35.000/hari, yang tentunya tidak mencukupi untuk kebutuhan sehari-hari serta biaya pendidikan tanggungan keluarga lainnya.

\section{KAJIAN PUSTAKA}

Dalam mengahadapi masalah kemiskinan, salah satu pendekatan pemecahan masalah kemiskinan di pedesaan yang dapat dilakukan adalah pemberdayaan masyarakat (community empowerment). Pemberdayaan masyarakat menjadi salah satu pendekatan yang kini sering digunakan dalam 
meningkatkan kualitas kehidupan dan mengangkat harkat martabat keluarga miskin. Konsep ini menjadi sangat penting terutama karena memberikan perspektif positif terhadap orang miskin yang tidak lagi dipandang sebagai orang yang serba kekurangan melainkan sebagai orang yang memiliki beragam kemampuan yang dapat dimobilisasi untuk perbaikan hidupnya.

Selain pemerintah pun organisasiorganisasi pelayanan sosial pun melakukan hal sama dalam konsep pemberdayaan masyarakat. Kehadiran program pemberdayaan masyarakat di Indonesia merupakan harapan bagi seluruh masyarakat terutama yang berada digaris kemiskinan. Namun sebenarnya yang menjadi masalah utama adalah bukan bagaimana program pemberdayaan terlaksana dan dapat mengeluarkan masyarakat dari garis kemiskinan, tetapi bagaimana porgram tersebut membuat mereka menjadi mandiri dan tidak ketergantungan. Sehingga dengan kemandirianya masyarakat dapat berpartisipasi dalam setiap tahapan program yang dilakukan oleh organisasi-organisasi pelayanan sosia dan berusaha keluar dari garis kemiskinan juga membuat pogram tersebut berkelanjutan.

Seperti yang di ungkapkan oleh sastroepoetro (1988), 4 bentuk partisipasi masyarakat yaitu :

1. Partisipasi pikiran, diberikan dalam bentuk diskusi dalam pertemuan atau rapat

2. Partisipasi tenaga, yaitu dalam berbagai kegiatan yang dicirkan oleh hasil kerja manusia untuk perbaikan dan pertolongan bagi orang lain

3. Partisipasi keahlian atau keterampilan, yaitu diberikan orang untuk mendorong aneka ragam bentuk usaha dan industri.

4. Partisipasi dengan materi, yaitu diberikan orang dalam berbagai kegiatan untuk perbaikan dan pembangunan. (Sastropoetro, 1988:56)
Melihat fenomea di atas Dompet Peduli Umat Daruut Tauhiid (DPU-DT) atau LAZNAS (Lembaga Amil Zakat Nasional) merupakan lembaga nirbala milik masyarakat yang bergerak di bidang penghimpunan (fundraising) dan pendayagunaan dana ZIS ( Zakat, Infak, Sedekah) serta dana lainnya yang halal dan illegal dari perorangan, kelompok, perusahaan atau lembaga. Latar belakang berdirinya Dompet Peduli Umat Daruut Tauhiid (DPU-DT) adalah melihat Indonesia sebagai negara yang dengan jumlah penduduk muslim terbesar di dunia memiliki potensi zakat yang sangat besar. Hal lain yang juga menjadi perhatian adalah belum optimalnya penggunaan dana zakat ini. Kadang, penyaluran dana zakat hanya sebatas pada pemberian bantuan saja tanpa memikirkan kelanjutan dari kehidupan si penerima dana.

Dari sana peneliti melihat sebuah potensi yang besar yaitu dari penghimpunan (fundraising) dana ZIS (Zakat, Infak, Sedekah) dan tertarik untuk mengetahui lebih jauh lagi, program yang di laksanakan oleh Dompet Peduli Umat Daruut Tauhiid ini salah satu nya adalah pada program Desa Ternak Mandiri (DTM). Program Dompet Peduli Umat Daruut Tauhiid (DPU-DT) yang khusunya pada Desa Ternak Mandiri (DTM) bertujuan untuk upaya penggemukan hewan ternak yang sasaranya untuk memberdayakan peternak kecil di pedesaan. Dompet Peduli Umat Daruut Tauhid (DPU-DT) memberikan modal kerja kepada dhuafa berupa kambing dan di tahap awalnya mereka di beri dua sampai lima ekor kambing, selain itu juga pada program Desa Ternak Mandiri (DTM) ini ingin memberdayakan masyarakat nya untuk mandiri dan tidak ketergantungan, jadi apa-apa yang dikerjakan oleh masyarakat di kembalikan lagi untuk masyarakat itu sendiri.

Dompet Peduli Umat Daruut Tauhiid (DPUDT) pun memiliki tahapan-tahapan dalam pelaksanaan program Desa Ternak Mandiri yang di antaranya :

1) Tahap penyerahan proposal

2) Tahap pemetaan wilayah 
3) Tahap pemetaan personal

4) Tahap rapat komite

5) Tahap MOU

6) Tahap pembentukan dan peresmian komunitas

7) Tahap pendampingan rutin

8) Tahap penjualan

9) Tahap pemutusan kontrak bila sudah mandiri

Desa Neglasari merupakan salah satu sasasran DPU DT dalam melaksanakan program DTM wilayah Jawa Barat. Penentuan lokasi atau sasaran penerima program tersebut melihat tingkat keluarga pra sejahtera yang tinggi, potensi pertanian, perternakan, juga sumber daya peternak yang harus dikembangkan, serta berusaha memperluas jaringan wilayah penerima program DTM di sekitar kabupaten Majalaya.

Oleh karena itu tujuan dari penilitian ini apakah partisipasi masyarakat terhadap program Desa Ternak Mandiri tersebut benarbenar mengurangi masalah kemsikinan yang ada di Desa Neglasari Kecamatan Majalaya Kabupaten Bandung.

Partisipasi masyarakat adalah salah satu kunci keberhasilan untuk mengatasi masalah kemiskinan, salah satunya yang di lakukan oleh Dompet Peduli Umat Daarut Tauhiid (DPU-DT), kunci dari keberhasilan yang dilakukan oleh DPU-DT adalah partisipasi masyarakat itu sendiri terhadap program yang diberikan yaitu Desa Ternak Mandiri. Beberapa hal yang menyangkut dengan partisipasi masyarakat adalah :

a. Pengertian Partisipasi Masyarakat : Dari rumusan tersebut, bisa diketahui, arti partisipasi bukan hanya sekedar mengambil bagian atau pengikutsertaan saja tetapi lebih dari itu pengertian tersebut terkandung tiga gagasan pokok, yaitu mental and emotional involvement (keterlibatan mental dan emosi), motivation to contribute ( dorongan untuk memberikan sumbangan), dan acceptance of responbility (penerimaan tanggung jawab). Seorang ahli ekonomi kerakyatan, Mubyarto (1997) mengatakan, pengertian dasar partisipasi adalah tindakan mengambil bagian dalam kegiatan, sedangkan pengertian partisipasi masyarakat adalah keterlibatan masyarakat dalam suatu proses pembangunan di mana masyarakat ikut terlibat mulai dari tahap penyusunan program, perencanaan dan pembangunan, perumusan kebijakan, dan pengambilan keputusan. Sementara itum sulaiman (1985: 6), seorang ahli pekerjaan sosial, mengungkapkan partisipasi sosial sebagai keterlibatan aktif warga masyarakat secara perorangan, kelompok, atau dalam kesatuan masyarakat dalam proses pembuatan keputusan bersama, perencanaan dan pelaksanaan program serta usaha pelayanan dan pembangunan kesejahteraan sosial di dalam dan atau di luar lingkungan masyarakat atas dasar rasa kesadaran tanggung jawab sosialnya.

b. Ada tiga tradisi konsep partisipasi terutama jika dikaitkan dengan praktik pembangunan masyarakat yang demokratis, sebagaimana dikemukakan Gaventa dan Valderama dalam Suhirman (2003), yaitu : Pengelompokan Partisipasi Masyarakat : 1) Partisipasi Politik : representasi dalam demokratis Tujuannya untuk mempengaruhi dan mendudukan wakil rakyat dalam lembaga pemerintah daripada melibatkan langsung masyarakat dalam proses-proses pemerintahan. 2) Partisipasi Sosial : keterlibatan masyarakat dalam proses pembangunan Masyarakat dipandang sebagai 'beneficiary' pembangunan dalam konsultasi atau pengambilan keputusan dalam semua tahapan siklus proyek pembangunan dari penilaian kebutuhan, perencanaan, pelaksanaan sampai pemantuan dan evaluasi program. Dengan demikian, partisipasi diletakan di luar lembaga formal pemerintahan seperti 
forum warga. 3) Partisipasi Warga : pengembalian keputusan langsung dalam kebijakan publik Warga berpartisipasi secara langsung dalam pengambilan keputusan pada lembaga dan proses pemerintah. Partisipasi menempatkan masyarakat tidak hanya sebagai penerima (objek), tetapi sebagai subjek dari kegiatan pembangunan yang dilakukan.

c. dikutip Soegijoko (2005), tingkatan partisipasi (dari yang terendah sampai tertinggi) sebagai berikut : 1) Berbagi informasi bersama (sosialisasi) : pemerintah hanya menyebar luaskan informasi program yang akan direncakanan atau sekedar memberikan informasi tentang program yang akan direncanakan atau sekedar memberikan informasi mengenai keputusan yang dibuat dan mengajak warga untuk melaksanakan keputusan tersebut. 2) Konsultasi/ mendapatkan umpan balik : pemerintah meminta saran dan kritik dari masyarakat sebelum suatu keputusan ditetapkan. 3) Kolaborasi/pembuatan keputusan bersama : masyarakat bukan sebagai penggagas kolaborasi, tetapi masyarakat dilibatkan untuk merancang dan mengambil keputusan bersama, sehingga peran masyarakat secara signifikan dapat mempengaruhi hasil/keputusan. 4) Pemberdayaan/kendali : masyarakat memiliki kekusaan dalam mengawasi secara langsung keputusan yang telah diambil dan menolak pelaksanaan keputusan yang bertentangan dengan tujuan yang telah ditetapkan dengan menggunakan prosedur dan indikator kinerja yang mereka tetapkan bersama.

d. Bentuk Partisipasi Masyarakat : 1) Partisipasi Pikiran : diberikan dalam bentuk diskusi dalam pertemuan atau rapat. 2) Partisipasi Tenaga : dalam berbagai kegiatan yang dicirikan oleh hasil kerja manusia untuk perbaikan dan pertolongan bagi orang lain. 3) Partisipasi Keahlian dan Keterampilan : diberikan orang untuk mendorong aneka ragam bentuk usaha industri. 4) Partisipasi Dengan Materi : diberikan orang dalam berbagai kegiatan untuk perbaikan dan pembangunan.

e. seperti dikutip Taher (1987:146-149) bisa dilihat dari motif, yang masing-masing bisa bekerja sendirian maupun bekerja bersamaan. Kelima motif tersebut adalah:

Motif Partisipasi Masyarakat : 1) Motif Psikologi : kepuasan pribadi, pencapaian prestasi, atau rasa telah mencapai sesuatu (achievment) dapat merupakan motivasi yangk kuat bagi seseorang untuk melakukan kegiatan atau partisipasinya itu tidak akan menghasilkan keuntungan (baik berupa uang maupun materi). 2) Motif Sosial : ada dua sisi motif sosial, yakni untuk ng status sosial dan untuk menghindarkan dari terkena pengendalian sosial (social control) orang akan dengan suka hati berpartsi di dalam suatu kegiatan (pembangunan) manakala keikutsertaanya itu akan membawa dampak meningkatnya status sosialnya. Pada sisi yang negatirf, orang akan "terpaksa" berpartipasi dalam satu kegiatan (pembangunan) karena "takut" terkena sanksi sosial (tersisih atau dikucilkan oleh warga masyarakat). Motif semacam ini dikendalikan oleh norma-norma sosial yang masih kuat di dalam masyarakat, terutuma yang masih bersfiat paguyuban. 3) Motif Keagamaan : Berbeda dengan motif psikologi yang didasarkan pada pencapian prestasi dan motif sosial berlandaskan status sosial dan pengendalian sosial, motif keagamaan didasarkan pada kepercayaan kepada kekuatan yang ada di luar manusia (Tuhan, sesuatu yang gaib, supernatural). Agama sebagai ideologi sosial yang mempunyai berbagai macam fungsi bagi pemeluknya, yaitu fungsi-fungsi : inspiratif, normatif, integratif, identifikatif, dan operatif/motivatif. Melalui aktualisasi fungsifungsi itu agama dapat meningkatkan perananya di dalam proses pembangunan, dan lebih dari itu agama dapat meningkatkan peran 
para pemeluknyaa dalam proses pembangunan.

\section{PENUTUP}

Kesimpulan yang dapat diambil ialah, pengentasan kemiskinan tidak semata-mata fokus terhadap program yang konsumtif tetapi lebih di tekankan program yang produktif. Program produktif tersebut lebih di tekankan kepada pemberdayaan masyarakat, pemberdayaan yang dilakukan harus melibatkan partisipasi masyarakat seperti Desa Neglasari Kecamatan Majalaya Kabupaten Bandung di berdayakan oleh DPU-DT dalam program Desa Ternak Mandiri yang saat ini sudah banyak merubah kondisi yang memprihatinkan ke pada kondisi yang lebih baik.

\section{DAFTAR PUSTAKA}

http://e-journal.uajy.ac.id/97/3/2EP17033.pdf (di unggah pada tanggal 24 april 2015 pada pukul 20.18 WIB.) http://digilib.uinsby.ac.id/7176/2/bab2.pdf (di unggah pada tanggal 24 april 2015 pada pukul 21.00)

Departemen Pendidikan Nasional, Kamus Besar Bahasa Indonesia (Jakarta: Balai Pustaka, 2005) hal. 831

Soejono Soekanto, Kamus Sosiologi ( Jakarta; Raja Grafindo Persada,1993), hal 355

Loekman Soetrisno, Menuju Masyarkat Partisipatif (Yogyakarta: Kanisius, 1995) hal.207

\section{Informan DPU-DT}

Jim Ife dan Frank Tesoreiro, Alternatif Pengembangan Masyarakat di Era Globalisasi Community Development (Yogyakarta: Pustaka Pelajar, 2008), hal. 296

Huraerah Abu, Pengorganisasian dan Pengembangan Masyarkat (Bandung : Humaniora 2011) 